\title{
The Long-Term Impact of a Short-Term Study Abroad Program: Perspectives on Global Citizenship
}

\author{
Todd M. Vanden Berg ${ }^{1} \&$ Lissa Schwander ${ }^{2}$ \\ ${ }^{1}$ Department of Sociology and Social Work, Calvin University, Grand Rapids, Michigan, USA \\ ${ }^{2}$ Department of Sociology, Anthropology and Social Work, Central Michigan University, Mount Pleasant, \\ Michigan, USA \\ Correspondence: Todd Vanden Berg, Sociology Department, Calvin University, 3201 Burton Street S.E. Grand \\ Rapids, MI 49546, USA. E-mail: tvdberg@calvin.edu
}

Received: April 18, 2019 Accepted: May 15, $2019 \quad$ Online Published: June 13, 2019

doi:10.5539/jel.v8n4p18 URL: https://doi.org/10.5539/jel.v8n4p18

\begin{abstract}
This paper explores the long-term impact of a short-term study abroad program on alumni of the program years after having taken the course. Through using a mixed measure survey, the data reveals that short-term study abroad programs can have a significant and direct impact on the lives of alumni. The specific program considered has impacted alumni choices of international tourist destinations, activities alumni participate in while traveling abroad, as well as the choices alumni make concerning lodging while traveling abroad. In short, after participating in a short-term study abroad program, alumni have developed a global citizenship identity.
\end{abstract}

Keywords: short-term study abroad, Jamaica, long-term impacts of study abroad programs, global citizenship, critical study abroad

\section{Introduction}

This paper explores the impact of a short-term study abroad program on travel and tourism decisions by alumni of the program. The program is a three-week course in Jamaica, focused on issues of international development with particular emphasis on the role of travel and tourism and the impact on Jamaica. The three-week course is one of several opportunities offered to students during Interim (a three-week January Term required for all students). This particular course has been offered ten times since 2002, and faculty involved have long wondered if the interim has had any long-term impact on alumni of the program.

Short-term study abroad programs (eight weeks or less) are by far the most popular form of study abroad at U.S. colleges and universities. Despite this, there is scant scholarship on the potential long-term impact of such programs. This study examines the long-term impact of this particular program on alumni, including decisions about travel and tourism, professional and volunteer activities, as well as intercultural understanding.

During the fall of 2015 a mixed measure survey was sent to alumni of the Jamaica interim using Qualtrics Survey Software. $56 \%$ of those surveyed responded. Data suggests that this short-term study abroad program has had a significant, direct, long-term impact on alumni. The program has impacted alumni choices of international tourist destinations, activities alumni participate in while traveling abroad, as well as the choices alumni make concerning lodging while traveling abroad. Alumni responses also indicate that intercultural sensitivity was positively impacted by the program. In short, alumni have moved to develop a global citizenship identity.

\section{Study Abroad Programs}

For much of the world today, intercultural contact is increasing in frequency and intensity (globalization), and in U.S. colleges and universities this can be seen in the ever-increasing participation of students in study abroad programs. The Institute of International Education (IIE) puts the number of U.S. students who participated in study abroad programs at 304,467 for the $2013 / 14$ academic year. This is a $62.8 \%$ increase from the $2003 / 4$ academic year $(191,231)$ (retrieved from IIE. 2015). "Profile of U.S. Study Abroad Students, 2003/04-2013/14." Open Doors Report on International Educational Exchange. Retrieved from http://www.iie.org/opendoors (see also Mach, 2011).

In addition to increased numbers of student participation, the nature and scope of study abroad programs have 
changed dramatically in recent decades. There has been a shift away from full academic calendar year programs toward short-term study abroad programs generally accepted to be from one to eight weeks long (Donnelly-Smith, 2009). Mary Dwyer, when looking at the data from The Institute for the International Education of Students Programs, found that in the 1950s/60s $72 \%$ of students participating in study abroad programs were abroad for a full year. In the 1990s this number had dipped to 20\% (Dwyer, 2004). At the national level, in 2015 , only $3 \%$ of U.S. students who studied abroad did so for an entire academic calendar year. $35 \%$ of the students studied for a quarter/semester, but the majority of students $(62 \%)$ who studied abroad did so in a short-term program (http://www.iie.org/Research-and-Publications/Open-Doors/Data/US-Study-Abroad/Infographic). Short-term study abroad programs dominate study abroad programs at an ever-increasing rate.

This study is conducted at a mid-size liberal arts institution in the Midwest that ranks \#2 nationally among baccalaureate institutions for students who study abroad during college (https://calvin.edu/academics/global/). The college offers eight international semester programs in Britain, China, France, Ghana, Honduras, Hungary, Peru, and Spain, as well as a semester in Washington D.C.

In the $2015 / 16$ academic year $70 \%$ (590) of students from this institution who studied abroad did so in off-campus interims/May terms while 30\% (249) did so in semester abroad programs. As for students who study abroad for a full year, the Director of Off-Campus Programs estimates that it is less than one student per year (personal communication).

\section{Literature Review}

Most attempts to measure the impacts of short-term study abroad programs do so through considering student's perceived attitudes or by indirect measures. For example, as Lisa Chieffo and Lesa Griffiths state in describing their study of short-term study abroad programs, "this project did not attempt to measure actual learning outcomes or changes in behavior. Instead, the results reflect perceived and recalled student activities and attitudes" (p. 167). Such approaches are the norm. It is not uncommon for such studies to use pre- and post-test assessment tools: the pre-test being given just prior to leaving on the short-term study abroad program, while the post-test is given immediately after returning or within a few weeks after return. A variety of measurement instruments have been used to analyze the impact of study abroad programs including the Cross-Cultural Adaptability Inventory (Mapp, 2012; Kitsantas, 2004), the Intercultural Development Inventory (IDI) (Kelley \& Meyers, 1993; Anderson, 2006; Rexeisen, 2008; Hammer et al., 2002, 2003; Jackson, 2008). The IDI is based on the Developmental Model of Intercultural Sensitivity (Bennett, 1993), which measures a respondent's developmental stage in guiding and limiting interaction across difference.

This project seeks to use direct measures to assess alumni attitude and experience with the study abroad program, but equally important, it seeks to examine alumni behavior, such as travel choices, as a result of participation in the program. We believe alumni attitudes and behavior that are more culturally competent and take into consideration local economies are a key component to global citizenship.

There are very few longitudinal studies of short-term study abroad programs, although the importance of such studies in order to improve international education has been noted (Anderson et al., 2006). Rexeisen and colleagues (2008) used a pre and post-test measure of the IDI four months after students completed short-term study abroad. Heather Rowan-Kenyon and Elizabeth Niehaus's (2011) case-study interviewed students one year after studying abroad. They found that "students who had engaged in subsequent learning opportunities continued to find meaning in their study abroad experience. The experience had faded into a distant memory for students who did not integrate the experience into their lives in some way" (p. 213). Both studies, though valuable, are not adequately longitudinal related to alumni behavior well after program participation and/or graduation.

Unlike short-term programs, semester long study abroad programs have been the subject of assessment, including longitudinal studies. Don Degraaf and colleagues (2013) focused on personal and professional development of students who participated in semester long programs while in college. Controlling for such things as location and length of the program, major area of study, and gender, this study reinforced the positive long-term impacts of semester-long study abroad programs. Richard Dukes and colleagues (1994) in their study of semester at sea alumni, 10 years after participation, found that the study abroad experience led to a maintenance of a global perspective and also contributed to positive personal growth of participants. Yemi Akande and Carla Slawson (2000) conducted a large-scale longitudinal study of alumni in programs of The Institute for the International Education of Students (IES). Their results also suggest a positive long-term impact on program participants. Respondents in their study reported benefits that included better understanding of self, openness to diversity and ease in interacting across difference, and improved language skills. A significant 
number of respondents (72\%) also reported continued travel abroad and $95 \%$ of respondents reported that their study abroad programs continued to influence their understanding of world events. Marianne McGarrity (2014) in a large-scale longitudinal study on alumni from the School of International Travel, examined the impact of study abroad programs on academic, professional and personal outcomes. This study concluded that study abroad programs influenced career choice and graduate study and furthermore suggested that study abroad alumni are highly accomplished and socially conscious, choosing education, health and nonprofit fields in large numbers (p. 1). In another large-scale longitudinal study spanning over 50 years, Mary Dwyer (2004a) concluded that "study abroad has a significant impact in the areas of continued language use, academic attainment measures, intercultural and personal development and career choices (p. 161). Dwyer also reports, however, that in some cases, participants involved in shorter term, non-semester long programs such as intensive summer study abroad programs, reported similar outcomes. She suggests that well planned, intensive programs can net significant outcomes across a variety of measures (p. 161). She notes that further study on short-term study abroad programs is needed to better asses their impact.

Michael Page and colleagues (2009) in their extensive research on the impact of study abroad programs also found that study abroad programs had positive impact on participants and their professional and personal engagement across several dimensions, including civic engagement and social entrepreneurship (p. S29). (see also Fry et al., 2009). Using date from the 2006 cohort of the Wabash National Study of Liberal Arts Education, Mark Salisbury (2013) in his study examining the effect of study abroad programs on intercultural competence found that such programs have significant effects on positive development of intercultural competence. However, he cautions that study abroad programs do not influence the "multiple domains that encapsulate intercultural competence equally" (p. 93). He reports that respondents were more inclined toward intercultural interaction; however, on other domains, such as comfort with diversity, there were not significant positive effects. Controlling for several variables, including pre-college characteristics and self-selection, Salisbury's research suggests "that study abroad influences students' diversity of contact but has no statistically significant effect on relativistic appreciation of cultural differences or comfort with diversity" (p. 2). He does conclude however, that even when controlling for several variables and factors, "on average, studying abroad significantly affects the positive development of intercultural competence" (p. 92).

We were interested in considering the development of global citizens in alumni, and as Dianna Murphy and colleagues argue, "developing global citizens is clearly a long-term outcome" (Murphy et al., 2014 p. 2). So, our goal was to see if our Jamaica Development Interim had a long-term impact on alumni behaviors

\section{Description of Jamaica Development Interim}

Our institution is one of 103 colleges/universities in the U.S. that have a January Term (Interim) http://diycollegerankings.com/beyond-college-rankings-january-terms-interim-terms-and-winter-terms/1295/.

Most interims are taken place between the fall and spring semesters, but there are a few that run as May Terms. Interims typically take place over a three-week period. Off-campus interims afford a wide variety of options for students to study abroad without committing to a full-semester study abroad program. At our institution, students are required to take three interims during their undergraduate experience as part of graduation requirements, and following a liberal arts philosophy, students are encouraged to take courses outside of their major; off-campus interims are popular. During the Interim of 2017, a total of 33 off-campus Interims/May Term courses were offered, 23 of which were international study abroad programs.

The Jamaica Development course was taught ten times between 2002 and 2019. Class sizes have grown over the years from 15 students in the first year to our most recent class in 2017 of 35 . Although the course content, lectures, and locations visited over the years have changed, the central theme of the Interim has always been to study issues of development relating to Jamaica, specifically the role of tourism as it relates to development. Additional topics studied during interims have included island history, colonialism, the African Diaspora, development theories, debt, corruption, remittances, migration, free-trade, and community development. We, along with faculty at the University of the West Indies, Mona, lecture on these topics. Other guest speakers include representatives of the World Bank, USAID, and representatives from local churches and social service agencies.

Beyond lectures, students are assigned and expected to read a considerable number of articles related to issues of development and tourism, as well as articles that introduce them to Jamaican society, systems and structures, and Jamaica's location in the global economy. Although readings have been updated throughout the years to reflect current issues and contexts, readings always seek to provide students with broad information about Jamaican history and the topics covered in the course (see Reader Table of Contents in Appendix B). The lectures and 
readings are tied specifically to the experiential component of the interim. Site visits include diverse organizations, including the University of the West Indies, a dairy farm, a coffee processing plant, a chicken processing plant, a coffee plantation, a spice factory, a sea turtle sanctuary, various community development organizations, local churches, and tourist attractions such as the Black River, YS Falls, Dunns River Falls, the National Art Gallery, Port Royal, Lime Cay, and the Pelican Bar. As discussed below, in all of the locations where we travel, we stay in Jamaican owned facilities (see in Appendix A the 2019 calendar and syllabus of the interim).

The course is developed and planned as an educational experience. Just as the readings and lectures are intentional toward this end, travel and lodging choices are also developed with the overall course theme in mind. We travel to four locations: Kingston, Mandeville, Treasure Beach, and Montego Bay.

Implicit in and foundational to the interim, we hope to afford students the beginning of the process of grappling with their place in an ever-increasing globalized context. We hope our students somewhere down the line will ultimately become global citizens. But as Davis (2006) has commented, the term "global citizen" is too broadly used to be useful, and so we follow Woolf (2010) who more specifically defines global citizen to mean, "someone who is, or who aspires to be, broad minded, intellectually engaged with other cultures, aware of the interdependence of nations, committed to tolerance and understanding of difference" (p. 48). We would add to this definition of global citizen, "someone who seeks to better the world for all its members." And so, our definition of global citizenship is:

Someone who is, or who aspires to be, broad minded, intellectually engaged with other cultures, aware of the interdependence of nations, committed to tolerance and understanding of difference, and someone who seeks to better the world for all its members.

We believe active engagement to better the world is a key element of global citizenship. We affirm Reilly and Senders (2009) call for study abroad programs to "deliberately position [themselves] as an active force in the service of global survival" (p. 262). They call this approach to study abroad programs "Critical Study Abroad." We attempt to achieve "critical study abroad" in our interim and have consciously attempted to structure our interim in order to afford the potential development of global citizens.

We do this in two ways. First, we hope to instill in students a self-awareness of their place within their cultural context. As Clyde Kluckhohn has famously said:

Ordinarily we are unaware of the special lens through which we look at life. It would hardly be fish who discovered the existence of water. Students who had not yet gone beyond the horizon of their own society could not be expected to perceive custom which was the stuff of their own thinking. Anthropology holds up a great mirror to man and lets him look at himself in his infinite variety $(1950$, p. 11).

This is a life-long task in that culture is continually changing and because culture is largely learned unconsciously. Such awareness is a key component of global citizenship.

Second, we hope to instill in students a positive attitude in approaching, and then interacting with, people from other cultures. Again, this is not natural for humans, as we are all inclined to ethnocentrism. As Hugh and Pauline Massingham state in The Englishman Abroad:

The born traveler - the [person] who is without prejudices, who sets out wanting to learn rather than to criticize, who is stimulated by oddity, who recognizes that every man is his brother, however strange and ludicrous he may be in dress and appearance - has always been comparatively rare (1962, XVII).

The Jamaican interim has been developed to stimulate students to think critically about their surroundings and the activities in which they are engaged during the study abroad experience and then to bring the lessons learned with them as they engage in future travel.

\section{Methods}

Research participants were limited to alumni who participated in the program between 2002 and 2013. Students participating in the 2015, 2017, and 2019 were not included due to continued enrollment in college at the time the survey was distributed. The survey was sent to 116 alumni of the program. Qualtrics survey software was to distribute the survey via email and to analyze the 16 Likert scale questions. The open-ended questions were independently coded by the investigators. The response rate of $56 \%(\mathrm{~N}=65)$ was encouraging, and we believe, hinted that the interim may indeed have had an impact on alumni.

The research questions directed to alumni of the Jamaican Development Interim focused on several issues: the role and impact of participation in the short-term study abroad program on travel and tourism decisions, 
participation in volunteering activities, increased intercultural/global sensitivity, and more broadly, life and career choices.

An alumni survey tracer using used mixed methods was sent to all participants of the interim prior to 2015 interim. The first section of the survey asked sixteen questions using a Likert scale from 1 (strongly disagree) to 10 (strongly agree). Three questions $(5,9,13)$ were taken from Zorn (1996). The majority of questions were original and specifically applied to the objectives/goals of the Jamaican Development Interim. The focus of these questions was on the travel/vacation habits of alumni, topics that lend both to a longitudinal survey as well as to potential measures of global citizenship. An additional open-ended question was included, affording alumni the opportunity to comment how they thought the interim impacted them. Open-ended survey questions included the following:

1) The Jamaica Development Interim has had a long-term impact on my interactions with people from other cultures.

2) The Jamaica Development Interim has affected the destinations I choose when traveling abroad.

3) The Jamaican Development Interim has affected my decisions on the activities I participate in when traveling abroad.

4) The Jamaica Development Interim affected my decisions on where I stay when traveling abroad.

5) The Jamaica Development Interim has caused me to reassess my outlook on life at home.

6) The Jamaica Development Interim has influenced career decisions that I have made since graduation.

7) The Jamaica Development Interim has facilitated an international or intercultural dimension to my volunteer activities.

8) The Jamaica Development Interim has facilitated an intercultural dimension to my social or religious activities.

9) The Jamaica Development Interim has contributed to my self-confidence.

10) The Jamaica Development Interim has affected my use of material culture.

11) The Jamaica Development Interim has affected my decision-making process on my use of disposable income.

12) The Jamaica Development Interim has enhanced my understanding of United States culture.

13) The Jamaica Development Interim has enhanced my understanding of United States politics.

14) The Jamaican Development Interim has influenced my discussions with others about international and trans-cultural issues.

15) The Jamaican Development Interim has affected my perspective on minority issues at home.

16) The Jamaica Development Interim has affected my perspective on minority issues abroad.

17) Please share with us how the Jamaica Development Interim has or continues to impact you.

According to the Open Doors Report on International Education Exchange, female participation rates in off-campus programs exceeds that of their male counterparts. They report that of those students participating in study abroad programs in 2014/15, 65\% were female and 35\% male (Institute of International Education, 2015). The female/male participation rate in the Jamaica Development Interim, as well as the survey response rate mirrors the national averages: $75.4 \%$ of respondents were female and $24.6 \%$ were male.

The Jamaica Development Interim is an inter-disciplinary course and draws students from many majors across the college. Students participating in the interim were from the following majors: Accounting, Art, Business, Economics, Education, English, Exercise Science, Geography, Interdisciplinary, International Development, International Relations, Nursing, Philosophy, Psychology, Speech Pathology, Social Work, Sociology, and Video Production. As mentioned previously, students are encouraged to take interims outside of their majors.

Most attempts to measure the impacts of short-term study abroad programs do so through considering student's perceived attitudes. This project attempts to gather information using more direct measures of analysis that move beyond assessing attitudes to reporting and measuring behavior.

Beyond the common use of indirect measures in assessment, most scholarship that attempts to study the impact of short-term study abroad programs distribute surveys immediately after the program is completed. We were interested in considering the potential long-term impact of short-term study abroad programs. With this in mind, our goal was to assess whether the Jamaica Development Interim had a long-term impact on alumni behaviors. Alumni received the survey between two and thirteen years from taking the interim. 
Studies assessing the impact of short-term study abroad programs often focus on topics of cultural sensitivity or global awareness, often considering issues such as intercultural awareness and personal growth. Although students participating in the interim are introduced to and in some ways immersed in a culture quite different than their own, intercultural development is not the primary goal of this particular interim. It is, however, embedded in the content, including readings, activities, lectures, and travel experiences that challenge students to think beyond their own experiences and understandings of the world. The content of this interim focuses primarily on the role and impact of international development on Jamaica, with a particular focus on the role of travel and tourism on the island. This content lends itself well, we believe, to assessing alumni behavior as a result of participation in the interim.

The theme of tourism is a major component of the interim, and students study the economics of tourism in Jamaica, the sustainability of tourism, eco-tourism, authenticity and tourism, cultural tourism, community tourism, and issues of leakage. Students also attend lectures and read multiple articles on these topics. Experientially, students move across different locations in Jamaica, experiencing travel and tourism on the island from many different perspectives. At the end of the interim, students spend a few days on the Hip Strip of Montego Bay - the historical epicenter of tourism in Jamaica. After spending most of the interim in Kingston, Mandeville, and Treasure Beach it is in Montego Bay that students participate in tourism from an etic perspective - often "feeling out of place" as one alumnus put it. Given our experiences with students engaged in this interim over the years and their reactions to "being tourists" at the end of their time in Jamaica, we believe that the study of tourism during the interim may impact alumni in their future choices of travel/vacations. This study speaks to that primary question with the majority of questions in the survey specifically addressing the tourism choices of these alumni.

\section{Limitations}

There are limitations to the methodology. The alumni survey has a selection bias in that those who participated in the survey were probably more likely to have had positive long-term impact from the interim experience. Further, the data can only suggest correlations rather than causation. In addition to this, as many of the studies discussed in the literature review, this study has no control group. That said, the study strongly shows the potential for short-term study abroad programs to have sustainable and direct impact on alumni.

\section{Results/Discussion}

For the Likert questions on the survey, we used the Net Promotor Score (Reichheld, 2003) to assist in measuring the long-term impact of our interim course. The Net Promotor Score (NPS) was originally designed to measure customer loyalty to a company and was originally based on one question: "How likely is it that you would recommend our company/product/service to a friend or colleague?" NPS scoring is typically based on a 1-10 scale Based on the original NPS question, respondents who score 9-10 are "promotors," considered likely to exhibit value-creating behaviors, remaining customers for longer, and making more positive referrals to other potential customers. Those scoring 7-8 are "passives," while those scoring 1-6 are considered "detractors"; such respondents are less likely to display value-creating behaviors. The NPS score is derived from subtracting the detractors from the promotors. The NPS score can be from -100 to 100. Any positive score is considered good, any NPS approaching 50 is considered excellent.

NPS scores have moved beyond the original question into broader questions. We used the NPS to measure "value-creating behavior" in terms of long-term impact of short-term study abroad programs. Our results were clear and dramatic. Five questions received positive NPS scores. The five questions that received positive scores can be considered specific indicators of the long-term impact of the interim.

Three of the five questions directly relate to issues concerning alumni travel practices. The remaining two concern issues relating to intercultural sensitivity and support previous scholarship that highlight the impact of study abroad programs on cultural sensitivity. We independently did content analysis on the open-ended question: "Please share with us how the Jamaica Development Interim has or continues to impact you." Our independent coding of this questions mirrors the NPS analysis. What follows are the five questions that received positive NPS scores, as well as examples of direct responses by alumni as we have coded them. We have given considerable space to alumni comments due to the strength of the comments, as well as our desire to honor the alumni who participated in the interim.

Q2: "The Jamaica Development Interim has affected the destinations I choose when traveling abroad." (7.9 NPS). 


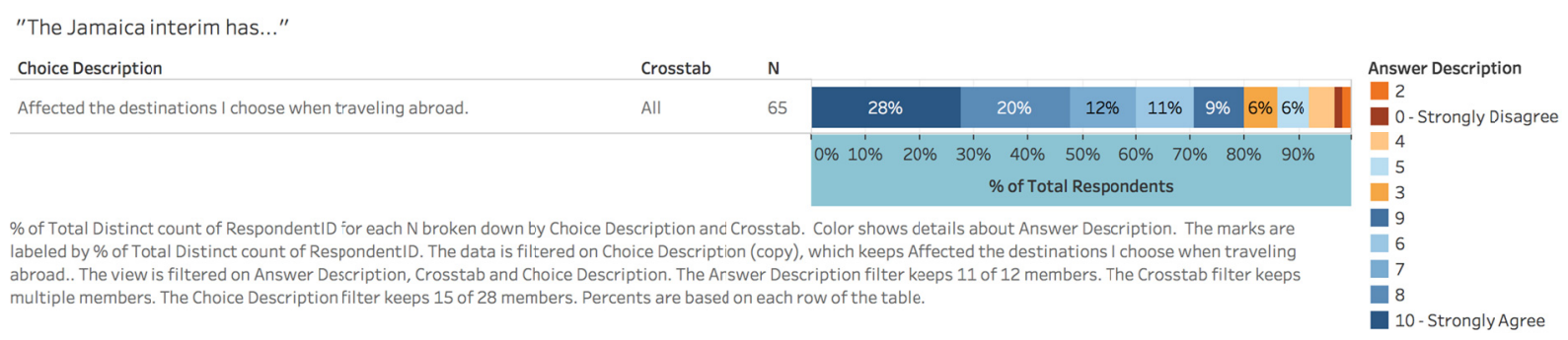

"When traveling I avoid all-inclusive resorts and I do not consider vacationing on cruise ships (influenced by watching Life and Debt and visiting Ocho Rios and Montego Bay). I have a better understanding of the impact of international trade policies and corporate investment in developing countries (Life and Debt, Alcoa's bauxite extraction plant). I understand the economic importance of products sourced and processed in country and give preference to those types of products (Blue Mountain Coffee, Pick-A-Pepper)."

Q3: "The Jamaica Development Interim has affected my decisions on the activities I participate in when traveling abroad." (32.31 NPS)

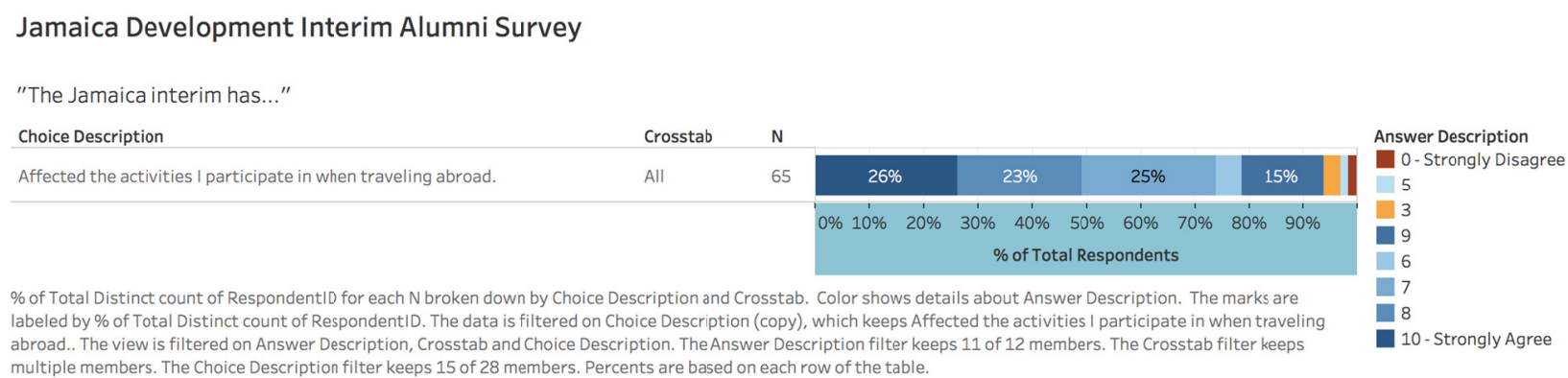

abroad.. The view is filtered on Answer Description, Crosstab and Choice Description. The Answer Description filter keeps
multiple members. The Choice Description filter keeps 15 of 28 members. Percents are based on each row of the table.

"In terms of long-term impact-I would argue this trip had more influence than all of my other interims... Even five years later, I can truly say this trip has had a lasting impact on the way I go about travel, and interpret different cultures and traveling decisions, whether it be lodging, food, environmental impact, or cultural impact."

"It [the interim] helped me also to understand how important it is to support small family owned and operated businesses."

"If I were to travel abroad again, I would want to ensure I am staying someplace that is beneficial to their economy and environment."

"I love to go on trips. Whether it is a night camping in a backyard, a weekend trip to the back woods of Kentucky or traveling through another country, I am a big fan. What I learned in Jamaica has contributed to all of the trips I have gone on since. Before that interim trip I did not think about how the things that my friends and I do, or where we eat, or where we stay has a direct effect on the dynamics of the place we are visiting. When vacationing our footprints, our dollars, and our stories have a direct effect on the economies, the environments, and the cultures of those places. I now am conscientious of sustainable tourism practices, staying with locally owned facilities, and getting to know the people in whose home we are guests."

"[The interim] taught me that because of the way the tourism industry works, traveling abroad somehow lands you in a place just like home and does not allow you to fully immerse yourself in the country you're visiting. The people and culture are what make a country — not the glamour of a resort. This interim trip was an eye-opening experience and something that has impacted my travel choices since."

Q4: "The Jamaica Development Interim affected my decisions on where I stay when traveling abroad." (4.69 NPS) 


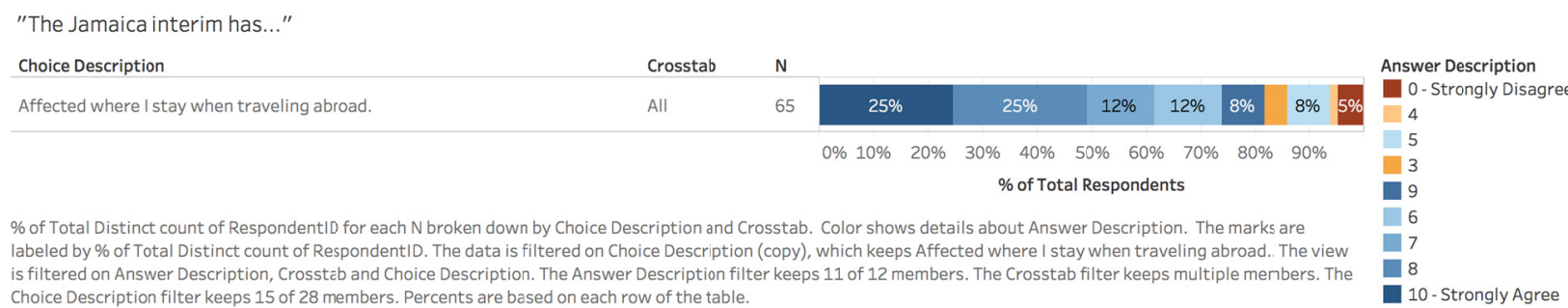

"It has impressed upon me the importance of supporting the local economies of the places I visit by intentionally choosing locally owned accommodations, restaurants, etc., and the importance of respecting the environment in the activities I choose to engage in.

I can truly say this trip has had a lasting impact on the way I go about travel and interpret different cultures and traveling decisions - whether it be lodging, food, environmental impact, or cultural impact."

Q14: "The Jamaica Development Interim has influenced my discussions with others about international and trans-cultural issues." (7.69 NPS)

Jamaica Development Interim Alumni Survey

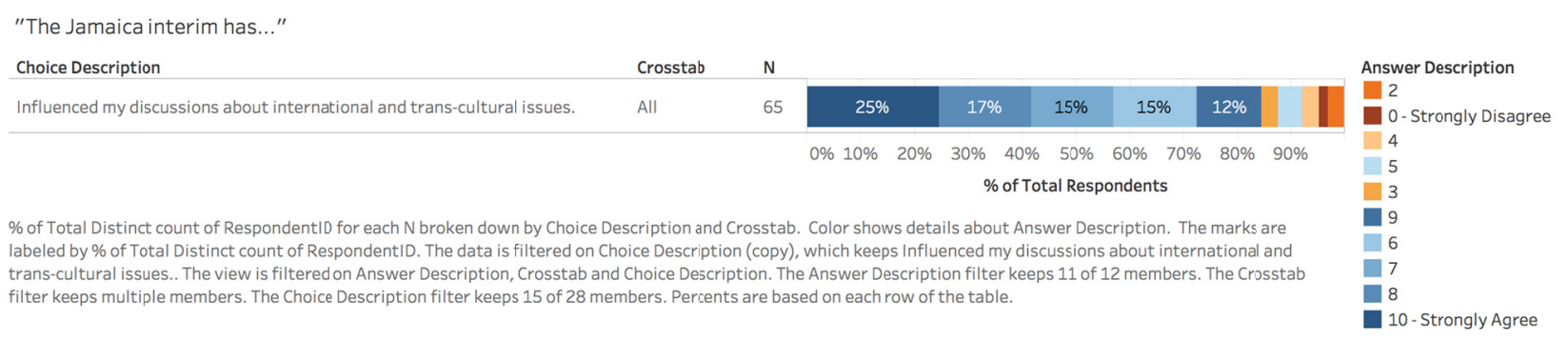

"I find myself more openly giving an opinion or feelings about tourist attractions that encourage the culture of that specific country and the tourist attractions that have been specifically made only for tourists rather than for a celebration of the culture of that specific country."

"I love telling people about my experience in Jamaica. I am quick to advocate for people living in third world countries especially when it comes to the tourist attractions and hotels. My passion to seek out natively run establishments I owe to my Jamaica interim. I want to be able to help put money back into their economy rather than foreign owned business that ship money back to the US and Europe. What an eye-opening trip! I loved every second."

"I think I'm less afraid to travel to 'bad' areas and countries and encourage others to do the same. So many people I have talked to about traveling to Jamaica all have said resorts and cruises convinced them it just isn't safe for white people to leave the compound! I never really felt unsafe, even late at night."

"I'm increasingly aware of others who take trips to Caribbean island nations and their activities, most involving some sort of all-inclusive resort or hotel. The trip has helped frame my conversations as well as what I would argue is a stable and socially responsible response to foreign travel."

Q16: “The Jamaica Development Interim has affected my perspective on minority issues abroad.” (9.23 NPS) 


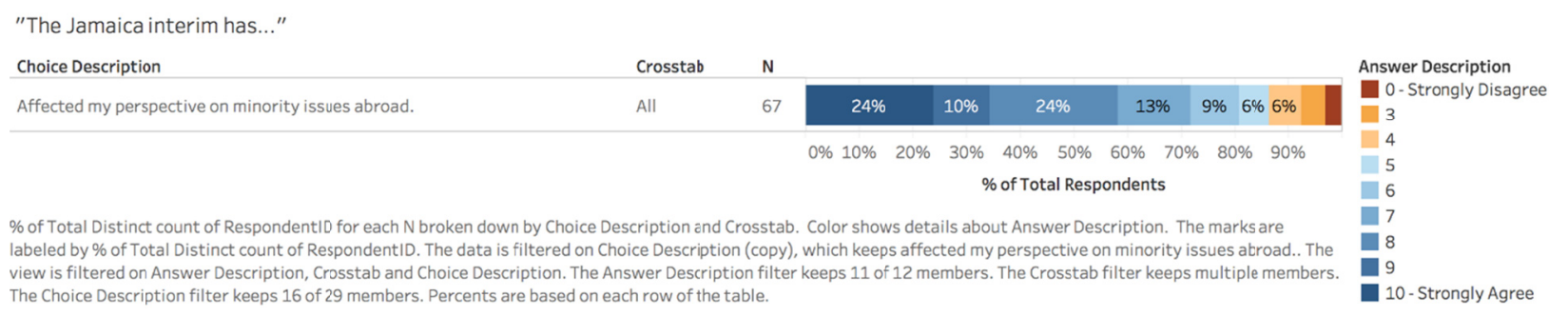

"[To] see how others view America, how our spending and political choices shape other cultures and countries was impactful for me. It becomes more real when you see it first-hand. I valued the experience as it helps you to see how much variety is in the world, how big it is, and yet how similar we all are to each other."

"I believe it [the interim] created a broad base of compassion for and interest in other cultures such that I approach new immigrants or refugees with enthusiasm and an openness to learn from their perspectives."

"This interim experience is in large part what led me to choose an internship my senior year at Calvin which involved working in the lives of foreign refugees with Bethany Christian Services. Which, in turn, has led me to believe that I am meant to serve a more diverse community, and the main reason I am pursuing graduate school for an MSW degree. The Jamaica interim along with travel to Haiti and Mexico, provided experiences outside of my comfort zone which have grown me in the healthiest of ways which is extremely valuable to me."

"My biggest lesson from the trip was there are no easy answers. The wide spectrum of people we interacted with showed how complex the issues were and so were the solutions. One more thing to note that still impacts me today. As a minority at Calvin, one of our biggest criticisms was how we segregated ourselves from the rest of the Calvin community. The Jamaican trip was one of the first times many of my white Calvin friends were ever minorities. What was interesting to me was how they exhibited the same traits they complained about us. So, for instance, even though opportunities existed to mingle with locals, they would still sit amongst themselves to eat. But the take away for me was the need to walk in another person's shoe to be able to understand their actions."

"The Jamaica Interim invited me to get a glimpse of the unique culture of Jamaica. It helped me also to understand how important it is to support small family owned and operated businesses. It allowed me to experience Jamaica in a way most Americans do not. I was fortunate enough to see the foundations of a beautiful country, but also the trials and challenges they face on a daily basis. I still speak about it today and have come in contact with native Jamaicans and I can have a conversation with them and understand better where they are from. So thankful I was able to be a part of such a great group and interim in Jamaica."

\section{Conclusions}

This project was designed to determine if short-term study abroad programs can have a long-term impact on alumni. We have shown that this is indeed the case. Years after participating in the Jamaica Develop Interim, alumni clearly and robustly identify how the interim has impacted them in actions/attitudes relating to travel/tourism as well as in their orientation to co-cultural and inter-cultural interactions.

Richard Slimbach states in his wonderful book, Becoming World Wise: A Guide to Global Learning, “...one of the central assumptions of this text is that merely learning about the world is not enough. Global learning must be not only in the world but also for it" $(2010$, p. 8$)$. He goes on to state that, "educational travel has a limited, though profoundly important, contribution to make to people's own development" (p. 23). We resonate with both of these sentiments and have made an effort in our Jamaica Development Interim to equip students to see themselves as global citizens with moral and even spiritual responsibilities to and partnerships with others in the world. Our data suggests that our alumni have indeed become global citizens, and that this is at least in part directly related to participating in the Jamaica Development Interim. We realize our data does not represent all short-term study abroad programs, but for those attempting to achieve the lofty goals set out by Slimbach for global learning, such objectives can indeed be reached-objectives that can have a profound and long-term impact on alumni and our ethno-sphere. We encourage all those involved in study abroad programs to set the bar high and develop study abroad programs that support life-orienting changes for students, as well as positive impacts on the host communities with whom the students interact. Doug Reilly and Stefan Senders in "Becoming the Change We Want to See: Critical Study Abroad for a Tumultuous World" (2009) suggest nine areas to 
consider when organizing a study abroad program that can produce global citizens and thus a better world. We highly recommend incorporating these areas when teaching a study abroad program.

\section{Acknowledgements}

The authors would like to thank Calvin University's Deur Award for financial support for this research. The Center for Social Research at Calvin University assisted with the Qualtrics survey as well as transcription services. The survey was reviewed and approved by the Human Subjects Institutional Review Board at Calvin University; document number 15-065.

\section{References}

Akande, Y., \& Carla, S. (2000). Exploring the long-term impact of study abroad: A case study of 50 years of study abroad alumni. International Educator, 9(3), 12-17.

Anderson, P. H. et al. (2006). Short-term study abroad and intercultural sensitivity: A pilot study. International Journal of Intercultural Relations, 30(4), 457-469. https://doi.org/10.1016/j.ijintrel.2005.10.004

Bennett, M. (1993). Towards Ethnorelativism: A Developmental Model of Intercultural Sensitivity (pp. 21-71). Aus: Paige, RM.

Bennett, M., \& Mitchell, R. H. (2002). The intercultural development inventory. Portland, OR: The IDI Corporation.

Chieffo, L., \& Lesa, G. (2004). Large-scale assessment of student attitudes after a short-term study abroad program. Frontiers: The Interdisciplinary Journal of Study Abroad, 10, 165-177.

Crumbauch, J. C., \& Leonard, T. M. (1969). Manual of instructions for the Purpose in Life Test. Psychometric Affiliates. https://doi.org/10.1037/t01175-000

Davies, L. (2006). Global citizenship: abstraction or framework for action? Educational Review, 58(1), 5-25. https://doi.org/10.1080/00131910500352523

DeGraaf, D. et al. (2013). The long-term personal and professional impacts of participating in a study abroad program. Frontiers: The Interdisciplinary Journal of Study Abroad, 23, 42-59.

Donnelly-Smith, L. (2009). Global learning through short-term study abroad. Peer Review, 11(4), 12.

Dukes, R. et al. (1994). A longitudinal study of a semester at sea voyage. Annals of Tourism Research, 21(3), 489498. https://doi.org/10.1016/0160-7383(94)90116-3

Dwyer, M. M. (2004a). More is better: The impact of study abroad program duration. Frontiers: The Interdisciplinary Journal of Study Abroad, 10, 151-163.

Dwyer, M. M., \& Peters, C. K. (2004b). The Benefits of Study Abroad. Transitions Abroad Magazine.

Fry, G. W. et al. (2009). Study abroad and its transformative power (p. 32). Occasional papers on international educational exchange.

Hadis, B. F. (2005). Why are they better students when they come back? Determinants of academic focusing gains in the study abroad experience. Frontiers: The Interdisciplinary Journal of Study Abroad, 11, 57-70.

Hammer, M. R., Milton, J. B., \& Richard, W. (2003). Measuring intercultural sensitivity: The intercultural development inventory. International Journal of Intercultural Relations, 27(4), 421-443. https://doi.org/10.1016/S0147-1767(03)00032-4

Jackson, J. (2008). Globalization, internationalization, and short-term stays abroad. International Journal of Intercultural Relations, 32(4), 349-358. https://doi.org/10.1016/j.ijintrel.2008.04.004

Kelley, C., \& Judith, E. M. (1993). The cross-cultural adaptability inventory. National Computer Systems.

Kitsantas, A. (2004). Studying Abroad: The Role of College Students' Goals on the Development of Cross-Cultural Skills and Global Understanding. College Student Journal, 38(3).

Kluckhohn, C. (1950). Mirror for Man: The Relation of Anthropology to Modern Life. Harrap.

Mach, A. (2011). Why Americans are choosing to study abroad in record numbers. The Christian Science Monitor.

Mapp, S. C. (2012). Effect of short-term study abroad programs on students' cultural adaptability. Journal of Social Work Education, 48(4), 727-737. https://doi.org/10.5175/JSWE.2012.201100103

Massingham, H., \& Pauline, M. (1962). The Englishman Abroad: With 12 pages of half-tone plates and 13 ill. in the text. Phoenix House. 
McGarrity, M. (2014). Long-Term Impacts and Outcomes: SIT Study Abroad.

Miville, M. L., et al. (1999). Appreciating Similarities and Valuing Differences: The Miville-Guzman Universality-Diversity Scale. Journal of Counseling Psychology, 46(3), 291. https://doi.org/10.1037//0022-0167.46.3.291

Murphy, D. et al. (2014). The Impact of Study Abroad on the Global Engagement of University Graduates. Frontiers: The Interdisciplinary Journal of Study Abroad, 24, 1-24.

Paige, R. M. et al. (2009). Study abroad for global engagement: the long - term impact of mobility experiences. Intercultural Education, 20(1), S29-S44. https://doi.org/10.1080/14675980903370847

Paige, R. M., Fry, G. W., Stallman, E. M., Horne, A., La Brack, B., \& Josic, J. (2007). SAGE Survey. Minneapolis, MN: University of Minnesota.

Reichheld, F. F. (2003). The one number you need to grow. Harvard Business Review, 81(12), 46-55.

Reilly, D., \& Stefan, S. (2009). Becoming the change we want to see: critical study abroad for a tumultuous world. Frontiers: The Interdisciplinary Journal of Study Abroad, 18, 241-267.

Rexeisen, R. J. et al. (2008). Study Abroad and Intercultural Development: A Longitudinal Study. Frontiers: The Interdisciplinary Journal of Study Abroad, 17, 1-20.

Rowan-Kenyon, H. T., \& Elizabeth, K. N. (2011). One year later: The influence of short-term study abroad experiences on students. Journal of Student Affairs Research and Practice, 48(2), 213-228. https://doi.org/10.2202/1949-6605.6213

Salisbury, M. H., Brian, P. A., \& Ernest, T. P. (2013). The effect of study abroad on intercultural competence among undergraduate college students. Journal of Student Affairs Research and Practice, 50(1), 1-20. https://doi.org/10.1515/jsarp-2013-0001

Slimbach, R. (2012). Becoming World Wise: A Guide to Global Learning. Stylus Publishing, LLC.

Woolf, M. (2010). Another Mishegas: Global Citizenship. Frontiers: The Interdisciplinary Journal of Study Abroad, 19, 47-60.

Zorn, C. R. (1996). The long-term impact on nursing students of participating in international education. Journal of Professional Nursing, 12(2), 106-110. https://doi.org/10.1016/S8755-7223(96)80056-1

\section{Appendix A}

\section{Globalization, Development, and Tourism in Jamaica Syllabus}

Interim 2019-January 3-22

IDIS W 47 - a 3 semester hours course

- a CCE (cross-cultural engagement) approved course

Instructors: Todd Vanden Berg and Bonnie Mulder

Course Description:

Jamaica with its vibrant multi-national urban center of Kingston, attractive tourist destinations and impoverished rural countryside, provides the backdrop for examining issues facing less developed countries. The interim exposes you to Jamaican culture and history, including the African diaspora, Jamaica's colonial experience, and Jamaica's contemporary identity in an ever-increasing globalized world. Through readings, engaging lecturers by faculty from the University of the West Indies/Calvin, representatives of various local and international organizations, we will examine the social and economic issues facing Jamaicans today including political unrest, tourism, debt, sustainability, migration, and the influence of the United States in Jamaican affairs. We will travel through both the interior and the coast of Jamaica seeing first-hand the various approaches to development/tourism occurring in Jamaica. Field trips will also be used to examine the various political, social, economic and international trends that have shaped the island and impacted its potential for successful development.

\section{Interim Objectives:}

At the end of the course students will be able to:

1) Describe various ways in which Jamaican culture, history, politics, and economics influence development 
efforts on the island,

2) Identify the various ways in which Jamaicans participate in globalization

3) Identify domestic and international challenges in development and consider how policy initiatives may resolve them,

4) Identify and describe the cultural and economic impact of tourism within the country,

5) Begin to develop a global citizen perspective,

6) Articulate a Christian response/perspective to the issues facing developing countries, particularly Jamaica,

7) Appreciate the rich history and culture of Jamaica and her people, and

\section{Possible activities while in Kingston:}

-Lectures at the University of the West Indies

-USAID lecture

-Devon House visit

-Port Royal tour

-Lime Cay Island visit

-Church service

-Art Museum

-Bob Marley Museum

-Dunns River Falls (Ocho Rios)

Possible activities while in Mandeville:

-Black River \& YS Falls Eco-tour

-Coffee Factory tour

\section{Possible activities while in Treasure Beach:}

-Boat tour and Pelican Bar visit

-Community organizations visit

-Sea Turtle sanctuary visit

Possible activities while in Montego Bay:

-Visit Negril

-Interviewing community members

-Beach participant observation

-Visit Rose Hal

Requirements:

1) Briefs - $20 \%$ of grade - In order to facilitate participation in the class sessions each assigned reading must have a written response - a brief. If no specific questions are assigned to the readings then the brief must address:

a. Your reaction to the reading (a couple of paragraphs per essay)

b. A minimum of two questions that can be raised in class drawn from the essay.

c. Each brief should be written on a separate page with the date, and title of the essay/author written on top of the page.

2) Personal Journal - $20 \%$ of grade - A daily journal must be written that reflects on your experiences of the day - academically or personally. This is a personal journal intended to help you to consciously reflect on your experiences. You will be asked to confirm that your journal has been written at the end of the interim but you will not have to hand in this journal due to the more personal nature of its content.

3) Cross-cultural Engagement - $20 \%$ of grade - To fulfill the CCE core requirement as well as heighten the value of this interim course, there is a reflective written paper required that considers issues of cultural diversity. There 
is no set length assigned to this paper. I recommend that you write this assignment while in Montego Bay-near the end of interim. The papers will vary based on student experiences over the interim, but possible topics of reflection may follow the below listed topics:

- How might a Jamaican understand globalization in ways similar/dissimilar to a person from the U.S.?

- Compare communication styles of U.S. and Jamaicans.

- What was the most significant frustration for you in your intercultural communication experience?

- What might you like to emulate of the Jamaican culture back in the U.S.?

- Compare your understanding of how Christianity is expressed in the U.S. to Jamaica. What might Christians in the U.S. learn from those in Jamaica and visa-versa?

- Has your view of the world changed in light of your time in Jamaica?

4) Getting Oriented Assignment from Slimbach $20 \%$ of grade - Follow the directions that are clearly articulated in this assignment. You will be required to have completed five of the orientation exercises. These five exercises will be converted into your Analytic Journal Response (AJR). Refer to the Slimbach essay for the procedure of this assignment. You can refer to the end of the Slimbach essay for examples of what AJR might look like.

5) Host community beach Interview - $20 \%$ of grade - This assignment will take place in Treasure Beach and Montego Bay and may be completed alone or in pairs. We will discuss the assignment while in Mandeville.

Summing up assignments to be handed in:

To successfully complete the interim course five written components must be handed in after arriving back in Grand Rapids.

1) Briefs on the readings.

2) A signed statement that you completed your personal journal.

3) The CCE component assignment.

4) The AJR from the Slimbach - getting oriented assignment.

5) Tourism Interview materials - signed consent form and completed interview

\section{Appendix B}

Reader Table of Contents

\section{Cultural Orientation (no brief for \#1 - Getting Oriented Assignment)}

1) Getting Oriented - Slimbach Author's permission for copies granted by Slimbach.

2) Chambers, Erve. 2005. Can Anthropology of Tourism Make Us Better Travelers? In Tourism and Applied Anthropologists: Linking Theory and Practice. Tim Wallace, ed. NAPA Bulletin 23. Pp. 27-44. http://onlinelibrary.wiley.com/doi/10.1525/napa.2005.23.1.27/pdf

3) Week, Laura. I am not a tourist: Aims and implications of "traveling." http://tou.sagepub.com/content/early/2012/07/20/1468797612454627.full.pdf

4) Wilk, Richard. Euphemisms for the Global Other. http://www.anthropology-news.org/index.php/2018/08/15/euphemisms-for-the-global-other/

Jamaica Overview (one brief for \#5 - 8, brief for \#9, brief for \#10)

5) Jamaica Profile (BBC) http://www.bbc.com/news/world-latin-america-18784062

6) Jamaica Country Profile (BBC) http://www.bbc.com/news/world-latin-america-18784061

7) Jamaica Overview (The World Bank) http://www.worldbank.org/en/country/jamaica/overview\#3

8) Jamaica Overview (USAID) https://www.usaid.gov/jamaica/history

9) Mason, Peter. 2000. History: Island of Conflict. In Jamaica: A guide to the people, politics, and culture. Peter Mason. New York: Interlink Books. Pp. 13-28.

10) Lewis, F. William. 2013. Urban Rastas in Kingston, Jamaica. In Magic, Witchcraft, and Religion: A Reader in the Anthropology of Religion. 9th ed. McGraw-Hill. pp. 278-383.

\section{Economic Development}


11) Griffith, Matthew. 2002. Case study of the impact of CAP on a developing country: importation of milk solids into Jamaica from the EU. Trocaire Development Review, Doublin, pp. 99-106. (ISSN 0790-9403).

12) Welch, Robert L, and Lius A. Vivanco. 2016. Chapter Seven, Economics: Working, Sharing, and Buying. In Cultural Anthropology: A Concise Introduction. Oxford University Press. pp. 124-141.

13) Isbister, John. 2006. Promises Not Kept: Poverty and Betrayal of Third World Development. 6th ed. Kumerian Press. pp. 1-6, 30-64, 226-238.

14) Sachs, Jeffery D. The Development Challenge. March April 2005. Foreign Affairs. Vol. 84. No. 2. pp. 7890.

15) Korten. David. From Relief to People's Movement. 1996. In Getting to the 21st Century. Kumerian Press. pp. 113-132.

\section{Tourism and Development}

16) Isaacs, Jack Coburn. The Limited potential of ecotourism to contribute to wildlife conservation. http:/globalforestcoalition.org/wp-content/uploads/2010/12/Ecotourism-Isaacs 1.pdf

17) Litvin, S. W., and K-A Fyffe. 2008. Tourism: A view from the fray.: A Jamaican case study. Int. Business and Globalisation, Vol. $2, \quad$ No. $\quad 2, \quad 160-172$. https://www.researchgate.net/profile/Stephen_Litvin/publication/240296165_Tourism_a_view_from_the_fray_a _Jamaican_case_study/links/55d3a11408ae7fb $244 \mathrm{f} 58 \mathrm{~d} 39 . \mathrm{pdf}$

18) Vanden Berg, Todd M. 2014. An Inquiry into Jamaican Perspectives on Tourism. Tourism, Culture, \& Communication. Vol. 14. No. 2. pp. 103-115. Author's permission for copies granted by Vanden Berg.

19) Conway, Dennis. Re-branding alternative tourism in the Caribbean: The case for "slow tourism." http://journals.sagepub.com/doi/pdf/10.1057/thr.2010.12

20) Hawkes, Ethan and Robert J. Kwortnik Jr. Connecting with the Culture: A Case Study in Sustainable Tourism. https://scholarship.sha.cornell.edu/cgi/viewcontent.cgi?article=1260\&context=articles

\section{Copyrights}

Copyright for this article is retained by the author, with first publication rights granted to the journal.

This is an open-access article distributed under the terms and conditions of the Creative Commons Attribution license (http://creativecommons.org/licenses/by/4.0/). 